1970, видатного німецького філософа, соціолога та музикознавця Теодора Адорно, яку переклав 3 німецької Петро Таращук (Київ: видавництво Соломії Павличко «Основи», 2002) [6, с. 234].

\title{
Література:
}

1. Гессе Герман. Гра в бісер / Герман Гессе; Пер. 3 нім. Є. Попович. К.: Дніпро, 1978. - 484 с.

2. Маслюченко В.К., Матвї̈шин Г.Я. Мистецтво і математика // УІІ міжнародна конференція «Математика. Інформаційні технології. Освіта». Світязь, 3-5 червня 2018. Тези доповідей. С.159.

3. Маслюченко В.К., Маслюченко Г.Я. Мистецький проект «Я формула» // УІІІ міжнародна конференція «Математика. Інформаційні технології. Освіта». Світязь, 2-4 червня 2019. Тези доповідей. С.160-161.

4. Шилов Г.Е. Простая гамма (устройство музыкальной шкалы) / Г.Е. Шилов. М.: Физматгиз, 1963. 20 с.

5. Вейль Герман. Симметрия / Герман Вейль. М.: Наука, 1968. 192 с.

6. Маслюченко В. К., Маслюченко Г.-Ж. Я.. Математика в мистецтві: Історія і сучасність // Прикарпатський вісник НТШ. Число 1(45). 2018. C. $230-234$.

7. Падаюча тінь «Мрії» на сади Джардіні. К.:OK Projects, 2019. 184 р.

DOI https://doi.org/10.30525/978-9934-26-178-7-32

\section{ДОСЛІДЖЕННЯ ЧИТАБЕЛЬНОСТІ НА ОСНОВІ АСОЦІАТИВНИХ ПРАВИЛ ГЕОМЕТРИЧНИХ ПАРАМЕТРІВ У РУКОТВОРНИХ ГРАФІЧНИХ ШРИФТАХ}

\author{
Пандирєва Є. А. \\ аспірантка кафедри теорї та історії мистеитв, \\ викладач кафедри візуальних практик \\ Харківська державна академія дизайну і мистеитв \\ м. Харків, Украӥна
}

Змінюючи пропорції літер, художник може надавати шрифту різноманітну ритмічну спрямованість - відчуття умовного руху, внутрішньої динаміки, яке викликане чергуванням повторюваних елементів літер. У літер з класичними пропорціями він відносно 
спокійний через стійкість і рівновагу всіх елементів, хоча ритм широких літер спрямований по горизонталі, а вузьких по вертикалі тощо.

Автор тез пропонує розглянути асоціативні правила на прикладі геометричних параметрів літер графіті, каліграфіті та рисованого шрифту. Параметри $є$ відносними і обрано за середньо статистичними характеристиками елементів літер. Актуальність теми дослідження полягає у тому, що основне призначення асоціативних правил - пошук закономірностей між параметрами у літерних елементах.

Мета: дослідити асоціативні правила 3 найбільшою читабельність на основі геометричних параметрів рукотворних графічних шрифтів (графіті, каліграфіті та рисованого шрифту).

Матеріали та методи: тези побудовано на основі системноаналітичного підходу. У дослідженні застосовано загальнонаукові (теоретичні та емпіричні) i спеціальні мистецтвознавчі методи наукового пізнання. Комплексне використання загальнонаукових теоретичних та емпіричних методів наукового пізнання дало змогу проаналізувати асоціативні правила на основі геометричних параметрів графіті, каліграфіті та рисованого шрифту для визначення найбільш оптимальної читабельності шрифту.

Результати та обговорення. По-перше, потрібно визначити зручність читання шрифтів за методикою вимірювання часу читання, яка полягає у вимірюванні швидкості (або часу) читання випробуваного напису, рукотворним графічним шрифтом (графіті, каліграфіті та рисований шрифт). Отримані експериментальні дані характеризують об’єктивну зручність читання досліджуваного шрифту.

По-друге, наступний етап роботи пов'язаний безпосередньо 3 виміром самих геометричних параметрів графіті, каліграфіті i рисованого шрифту [2]:

1. Пропорційність - відношення висоти до ширини;

2. Контрастність - відношення основного штриха до ширини додаткового штриха;

3. Відношення максимальної товщини штриха до мінімальної товщини;

4. Відношення величини всіх літер у написі до висоти окремо обраної літери;

5. Площинність літер;

6. Відношення площини на якій знаходиться літера до пропорційних співвідношень самої літери.

Найбільшу достовірність отримали правила з параметрами «Основна висота шрифту на висоту окремо взятої літери», «Основний штрих на 126 
внутрішньо літерний просвіт», «Контрастність» (максимальна ширина штриха на мінімальний). Розглянемо асоціативні правила за якими визначаються найбільш читабельні шрифти:

1. Правило «Якщо відношення площини на якому знаходиться літера має невелике значення (кількісно обчислені геометричні параметри), то контрастність теж має невелике значення». Різниця між площиною, на якій розташовується літера, і висотою літери невелика, то різниця між основним штрихом і додатковим теж відносно невелика, хоча може бути й зворотньою (додатковий штрих ширше основного).

2. Правило «Якщо відношення площини на якому розташована літера на висоту літери має невелике значення (кількісно обчислене), то основний штрих на внутрішньо літерний просвіт є маленьким». Різниця між основним штрихом і внутрішньо літерним просвітом стандартна (просвіт завжди значно більший), цей висновок був зроблений на основі графіті, каліграфіті та графіті. Шрифти, що займають значну частину площини на якій вони розміщені, при цьому мають значний внутрішньо літерний білий простір.

3. Правило «Основний штрих на внутрішньо літерний просвіт повинен бути маленьким». Для зручності читання шрифту внутрішньо літерний просвіт повинен на певну невелику величину (кількісно обчислену), перевищувати основний штрих.

4. Правила із середньою достовірністю читабельності, це параметри: «Контрастність», «Пропорційність» та «Площа на периметр». Усі рукотворні графічні шрифти, що розглядаються, мають цю залежність, проте вона у кожного шрифту виражена по різному.

5. Правила 3 низькою достовірністю читабельності вже менш значущі, варто лише відзначити, що їх складають у різних варіаціях параметри «Основний штрих на внутрішньо літерний просвіт», «Контрастність», «Площа на периметр» і «Площина на якій розташована літера на висоту» [3]. Зазвичай, до правил 3 низькою достовірністю відносять більшість видів графіті. Проте, як вважають дослідники, саме графіті серед всіх рукотворних графічних шрифтів мають найскладнішу морфологію літерної-форми.

Висновки. Отримані результати підтверджують, що для високої зручності читання шрифту дійсно сприяють певні геометричні параметри, тому зробимо наступні висновки:

Графіті літери виявили найбільшу відмінність у пропорційних співвідношеннях: по відношенню висоти до ширини, по відношенню основного штриха до ширини додаткового штриха, по відношенню максимальної товщини літерних елементів до мінімальної їх товщини. 
Якщо проаналізувати величину однієї обраної літери у написі та порівняти iï 3 величинами інших літер у цьому ж написі, то їх пропорційність може кардинально змінюватися. Слід також зазначити, що площинність літер у графіті варіюється від об'ємних 3D літер, до плоских (рис. 1).

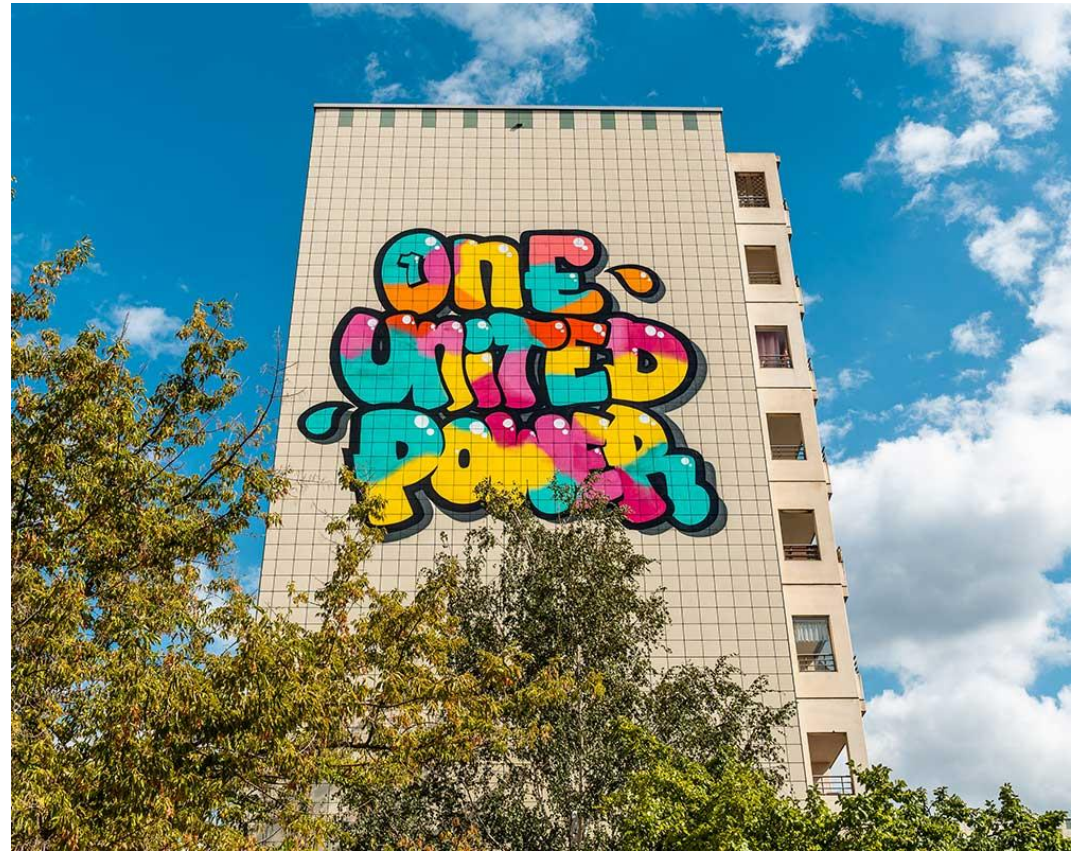

Рис. 1. 1up. «One united power». Märkische Allee 160. Берлін, Німеччина. 2019

Літери каліграфіті мають пропорційні співвідношення, які максимально наближені до пропорцій класичної каліграфії: у відношенні висоти до ширини, у відношенні основного штриха до додаткового, у відношенні максимальної товщини до мінімальної товщини. В основному, літери в каліграфіті мають майже завжди однакові величини по відношенню один до одного. Щодо площинності літер, то вони завжди є плоскими (рис. 2). 


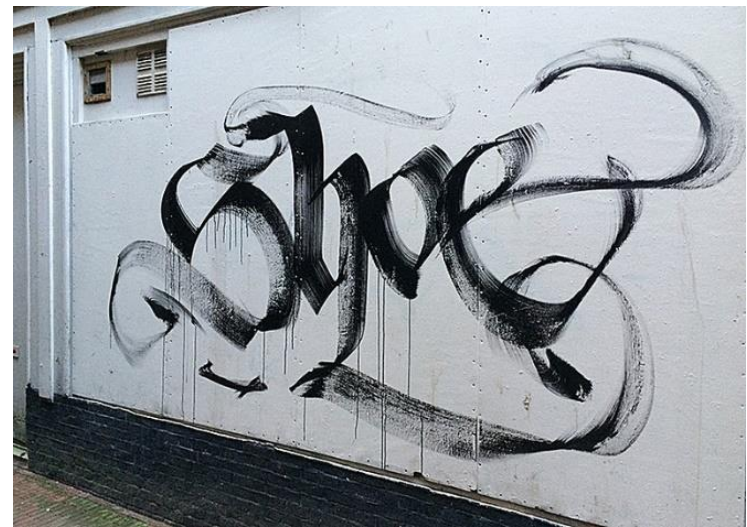

Рис. 2. Shoe. «Shoе». вул. Дамрак, Амстердам, Нідерланди

Рисовані літери мають різне відношення висоти до ширини, відношення основного штриха до ширини додаткового штриха та відношення максимальної товщини штриха до мінімальної товщини штриха. Якщо порівнювати висоту якоїсь обраної літери з висотою літер, які стоять поруч у написі, то можна виявити відмінність, але не суттєву. Рисовані літери можуть бути як об'ємними, так і плоскими (рис. 3).

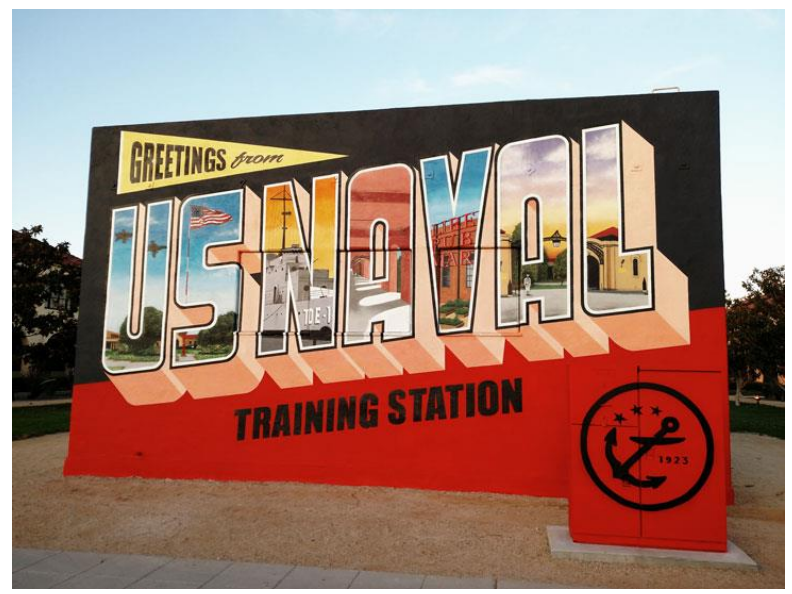

Puc. 3. Victor Ving. «US Naval. Training station». 2875 Dewey Rd, Сан-Дієго, штат Каліфорнія, США 


\title{
Література:
}

1. Зільберглейт М. А. Методика та техніка підготовки курсових та дипломних робіт. Мінськ: Біл. наука. 2003.

2. Токар О. В. Зручність сучасних текстових шрифтів: наукове видання. Мінськ: ТОВ «Сучасна школа». 2007.

3. Токар О. В. Побудова асоціативних правил на основі зв'язку геометричних параметрів шрифтів та об'єктивної зручності читання. Технологія та техніка друкарства. Київ: ВПІ НТУУ «КПІ». 2013. 40-46.

\section{DOI https://doi.org/10.30525/978-9934-26-178-7-33}

\section{РОЛЬ ДИСЦИПЛІНИ «РИСУНОК» У ФОРМУВАННІ ПРОФЕСІЙНИХ КОМПЕТЕНТНОСТЕЙ МАЙБУТНІХ БАКАЛАВРІВ ДИЗАЙНУ}

\author{
Рашевська А. А. \\ викладач кафедри дизайну \\ Запорізький наиіональний університет \\ м. Запоріжжя, Украӥна
}

Проблема якості та набуття відповідних професійних компетентностей, що являються основними для формування творчих особистостей, гостро стоїть перед сучасною мистецькою освітою. Тому досить актуальним є питання підвищення творчої грамотності студентів, шляхом збереження кращих традицій академічної школи, розвитку знань, умінь і навичок в художньо-графічній діяльності на заняттях 3 «Рисунку», використання ефективних форм і методів роботи в підготовці бакалавра дизайну.

Дослідженням питання формування компетентностей в дизайн-освіті займались такі українські вчені як О. Бойчук [1], О. Васіна [2], О. Пальцун, С. Мільчевич, В. Неня та інші, які своїх працях приділяли значну увагу саме художньо-графічній діяльності. Так, зокрема, зазначається, що художньо-графічна діяльність - процес соціальний, пов'язаний з духовно-практичним освоєнням середовища, який сприяє втіленню змісту діяльності і їі гуманістичної спрямованості в емоційнообразній формі, яка забезпечує естетичне сприйняття світу.

В процесі освоєння дисципліни «Рисунок» у студентів формуються навички цілісного світосприйняття, що виражається у відчутті ритму, форми, пропорцій; естетичний смак; вміння дати художню оцінку; 